\title{
Changing roles for research and information skills development: librarians as teachers, researchers as learners *

\author{
Tatiana Sanches
}

\author{
'Instituto de Educação, Universidade de Lisboa, Lisboa, Portugal \\ 'ISPA, Instituto de Psicologia Aplicada, APPsy Center, Lisboa, Portugal \\ tsanches@fpie.ulisboa.pt
}

\begin{abstract}
University libraries have been dealing with the training needs of their users for a long time. Today, this need continues to be pressing with day to day immersion in print and digital information and the transformations of the tools for its access. Librarians play a fundamental pedagogical role for teachers and researchers who are urged by the Open Science movement to acquire new information skills. They develop information literacy training adapted to these needs. The paper presents a case study that explains three pedagogical paths: tutorial support for teachers and researchers in their daily lives; the provision of electronic resources and training for its proper use; and the development and dissemination of an online publication that seeks to improve their knowledge and practice skills related to Open Science. The actions that librarians can develop are vital because they are the basis for the creation and application of cross-curricular skills in lifelong learning, so necessary for teachers and researchers who need to quickly adapt to new information contexts.
\end{abstract}

Keywords: Information Literacy Training, University Libraries, Teachers, Researchers, Open Science, Information Skills, Higher Education.

\section{Introduction}

The pedagogic roles of librarians are becoming more and more important in daily life. With the digital age, new opportunities arise for librarians to act as protagonists, advocates, and pioneers of a new way of handling information, overcoming the traditional roles of keepers and carers of collections [1]. Researchers, on the other hand, as stated by the Working Group on Education and Skills under Open Science [2], need to prepare themselves for the Open Science movement by acquiring new skills.

The commitment of higher education libraries to support research and science has been pursued through several ways: digital data management, institutional repository maintenance, close linkage between technology services and library services, and

\footnotetext{
* The final authenticathed version is available online at https://doi.org/10.1007/978-3$\underline{030-13472-3 \_44}$
} 
digital archiving of content aggregators that allow interaction and interoperability between databases [3-4]. However, this support should also be given through more direct actions that encourage the acquisition and development of skills by researchers and the good use of tools that improve their day to day [5].

Based on a literature review that underpins a case study, the study seeks to contribute to this reflection, explaining training strategies aimed at researchers, particularly with regard to tools and skills that can contribute to the research, organization, and presentation of information. The case study describes how an academic library responds every day to the challenges of Open Science, taking three paths: providing tutorial support to teachers and researchers; investing in electronic resources and training for their proper use; and developing and disseminating an online publication that seeks to improve their skills in both knowledge and practices relating to Open Science. The library thus seeks to advocate for Open Science, giving the teachers and researchers greater confidence by promoting transversal competences, which facilitate greater participation in the global dissemination of scientific knowledge.

The conclusion shows that these are fundamental partnerships [6-7] and that the actions librarians can develop at this level are vital, for they are the basis for the creation and sustainable development of transversal skills in lifelong learning, particularly in the changing landscape of higher education.

\section{$2 \quad$ Librarians as teachers}

\subsection{The pedagogic role of the academic library}

More than ever, it is urgent that libraries assume their pedagogic role. This is not a new topic, particularly in university libraries, and has been widely discussed in the last decades. As early as 1957, Harvard-Williams [8] had already reflected upon the place and function of the university library, suggesting that, given its growing complexity and the proliferation of books and journals, the most efficient process to make good use of a big library is to consider its pedagogic role [8]. Kemp [9] lists the benefits for librarians related to developing pedagogic skills: learning to interact with students; increasing sensitivity to students' concerns and needs, administrative requirements and teaching faculty overload; changing priorities for developing library collection; enhancing library status and feeling "equal" to other faculty; enjoying intellectual stimulation due to teaching activities; and the academic librarian's self-improvement, which benefits the whole academic community.

The pedagogic role of librarians becomes more pressing as teaching itself focuses on search methods and on constructivist learning, of which research techniques and information literacy are fundamental elements [10]. The essential idea is that the efficient and productive use of information sources and resources, received through good pedagogic strategies, will bring tangible benefits to users, in that they can connect resources and research in a more fluid, intelligent manner. These are practical results for students who want to have a successful academic career and for teachers and researchers whose action and professional development may find a sound partnership in libraries. Indeed, as repositories and places of access to information, libraries are a 
vital key of the chain of intellectual production and scientific advancement, precisely because they also identify with the same mission of teaching, research, and dissemination of knowledge as the universities where they belong. While not all librarians feel comfortable in the role of teacher [11], the pedagogic role of academic libraries is recognized as an essential feature of the organizational mission and must move from emergent practice to best practice [12].

\subsection{Librarians, teachers and researchers partnerships}

To implement its pedagogic role, libraries have taken paths that, one way or another, lead them to the development of partnerships with teachers and researchers. In 1993, Grimes [13] already mentioned the importance of these synergies, calling for librarians to develop pedagogic skills and the faculty to develop research skills, with a view to equalizing both roles in their shared contribution towards students' learning.

Among other advantages, the positive impact of good relations, shared values, and focus on communication are pointed out as boosters of commitment and trust between faculty and librarians [14]. Partnerships are also recognised as generating value in libraries and it is recommended librarians invest in the development of their teaching skills, show confidence in the field of their abilities and librarianship skills, and invest in communication [15]. This is why several studies [5], [7], [16-18] point in the same direction: a successful collaboration between librarians and teachers seems like a winwin deal, with obvious gains for students and researchers, who reach their academic goals with greater efficacy, are more up-to-date in their study topics and expand their study and research skills. As Dillon states [19, p. 57], "Augmenting the learning and research processes will require a deeper understanding of the underlying psychology and culture of these creative acts and experiences, coupled with an ability to experiment with and evaluate the effects of new tools. Libraries are not alone in this effort, and partnering with faculty in exploring new practices is necessary for real progress to occur."

In Portugal, there are already reports of successful experiences [20-21] in the framework of partnerships between teachers and librarians, particularly in the context of the construction of training in information literacy. This is seen in examples to follow.

\subsection{Training teachers and researchers in information literacy}

As mentioned at the beginning, in a vastly changing informational context, it is clear that information literacy continues to be relevant and contemporary in the academic community, especially to meet the needs of researchers and teachers. Thus, the training of these professionals should also be a priority for librarians [22]. We should deal naturally with the fact that teachers and researchers are not as updated in terms of information management, digital data, or virtual profiles, though all these tasks are closely related to their daily activity. To respond to these demands, the flexibility and 
scope of information literacy are strengths to be taken advantage of. Due to the specific needs of faculty, contents, formats, and evaluation must be tailored to each specific situation, as they already are for students [23-24], and based on effective communication between the recipients of the actions and those providing them. In fact, there are already national and supranational concerns seeking to ensure an appropriate coverage of information skills and competencies training and skills development programmes for researchers [25-26]. But these concerns should be applied to the concrete everyday situations of our libraries, particularly considering the context of Open Science and what its concepts and practices imply for teachers and researchers.

\section{$3 \quad$ Researchers as learners}

\subsection{Open Science and new needs}

Open Science $[27,28]$ represents a new approach to the scientific process, based on cooperative work and new ways of distributing knowledge by using digital technologies and new collaborative tools. It also represents the transitions under way concerning how research is carried out, how researchers collaborate, how knowledge is shared, and how science is organised. In practice, Open Science can make science more credible, trustworthy, efficient and respondent to societal challenges [29-30]. So it is only right to bet on its dissemination, promoting its benefits and supporting researchers to participate and enjoy these advantages. But this can only be achieved with information and training.

In the United Kingdom, United States, and some Northern European countries, concerns with the development of research skills supported by librarians seem to have more emphasis [22], [30-32]. Actually, it is widely recognised that university libraries have supported science and research [33]. They do so through several means:

- through providing information resources such as offering search engines for searching information and acquiring the necessary resources;

- in its conservation and access, providing the means to keep, preserve and safeguard materials; and,

- in supporting and facilitating teaching activities and research processes through which they help undergraduate students develop research, critical analysis, and skills in information literacy.

The Ministry of Science and Higher Education in Portugal created opportunities for a national debate, involving the different players in the construction of a common commitment towards the democratisation of access to knowledge through making recommendations concerning Open Access [34]. These are based on European guidelines and focus on the definition of an agenda for science and innovation, grounded in the concepts of Open Science, Open Innovation, and Openness to the World. Focused mainly on a change of paradigm regarding research operated by these concepts, these concerns [35-36] are also emerging in Portugal. This is seen as an interweaving of the modus operandi of research in the context of Open Science with the 
resources and tools available in the digital environment, especially through libraries [37] and by developing skills in information literacy [38].

\subsection{Information Skills Development}

Transversal skills, that go beyond the disciplinary spectrum of researchers' fields of interest, add greater capacity for intervention, because they not only benefit their role of information promoters but they also allow them to develop the ways in which they search, learn, and are updated $[39,40]$. So which new skills should researchers develop? The challenge of demands set by more data, more information, more scientific production, more national results that can be used in rankings, impact factors, and other metrics, is compelling. In an in-depth study about the use of libraries by researchers [31], the authors concluded that researchers and librarians have different perceptions regarding researchers' needs. The various aspects where common work is the priority were listed and include

- funding needs to acquire documentation and fostering a sense of belonging to the library;

- improvement of behaviour towards information;

- new ways of working - collaborative and interdisciplinary;

- new ways of supporting researchers through counselling and training;

- visibility, dissemination, and openness supporting open access;

- the need to promote library services; and,

- ensuring communication channels.

These are important clues to define the skills that must be worked on by librarians, so that they respond adequately to researchers' needs. It also confirms, as stated almost a decade ago, the librarians' growing and expansive role as educators, as higher education responds to an ever-changing world [40].

\section{$4 \quad$ A case study}

The Instituto de Educação [Institute of Education] (IE) is an organic unit of the University of Lisbon, designed for research, training, and intervention in the realm of Education and Training. The Faculdade de Psicologia [Faculty of Psychology] (FP) is also part of the University of Lisbon and is dedicated to forming future psychologists and to intervening in individual and collective behaviour. The library that is the object of this study serves both institutions simultaneously. For this purpose it has a team of seven people. In total, the library serves an academic community of 2,250 students, teachers, and researchers. The support given by university libraries to teachers and researchers is neither new nor is it exclusive of this case in particular. This library has supported teachers and researchers for some years already, albeit in different formats, and has been the object of study at several times [41, 42].

The present study intends to explore the way researchers can take advantage of the context of Open Science to prepare specifically for dealing with information and to 
show the responses of the librarians sustained in information literacy. The aim is to clarify that by knowing how to search, select, organise, evaluate, and present information in an ethical and legal manner, they will have better conditions to investigate, produce new knowledge, and spread it. This study thus seeks to show the support of higher education libraries, indicating tools and good practices to train and inform, as an answer to this aspiration.

\subsection{Preparing, organizing and projecting research}

Although there are more detailed proposals [43] regarding the research cycle associated with the support of libraries, in the case in question we chose to provide training that takes into account the information and capacity-building needs regarding the researchers' actions, on three levels:

a) Preparing the investigation

- Supporting the purchase of documentation

- Supporting the search for information

- Advanced search in specific databases and search engines

b) Organising and developing the investigation

- Supporting the organisation of information

- Quoting and referencing

- Electronic management of bibliographic references

c) Designing and disseminating the investigation

- Checking self-archive rights

- Managing the repository

- Supporting self-archive and validation of data

- Impact factors

- Creation and management of researcher profiles

- Supporting choice of publications for publishing

- Supporting the preparation of Powerpoint and oral presentations

- Highlighting the investigation's publications/results

For all these needs, four concerted strategies are organised that imply thinking about the investigation globally: a) tutorial support for researchers, considering various individual requests; b) investing in electronic resources and tools; c) providing specific training in two-hour workshops; and d) developing and disseminating an on-line informative publication to improve researchers' skills both in knowledge and in practices concerning Open Science. Together, these areas ensure that we meet the proposed informative and formative goals, giving researchers' greater confidence by promoting the necessary transversal skills. They also contribute to strengthen their presence in research networks, consequently offering greater participation in the global distribution of scientific knowledge. We know that researchers have different appetites when it comes to information, but it is also known that there are vast common grounds with regard to Open Science, to which we can turn our attention and provide training through various channels. 


\subsection{Reframing information skills for researchers' needs and building partnerships for learning}

A combination of new roles, new abilities, and new partnerships may help librarians to efficaciously and efficiently extend their services and respond to a wide range of researcher needs [22]. The library in question aims to correspond to this aspiration. Throughout the years, it has developed several actions to support research by:

- Purchasing and making available databases, electronic journals, books, and other that sustain data search and collection and substantiate the scientific investigation;

- Supporting researchers in knowledge production and management through training actions/workshops and tutorial assistance with regard to research resources and to themes such as management of bibliographic references, impact factors, and so on;

- Encouraging research study and dissemination of research findings by creating research profiles as well as its publication in open access, in the institutional repository, and in academic social networks, , thus ensuring the scientific production has international impact.

The amount of information currently available requires that researchers have the necessary skills to search, evaluate, select, use, and present information in an ethical, efficient manner. Hence, the importance of transversally following the whole research process. Regarding the impact of information literacy on Open Science, Basili [44] states that it is important to promote skills that enhance the capacity to critically confront contents, self-sufficiency, and control over the learning/research process. Generally speaking, researchers manage their investigation and have skills concerning information search strategies, evaluation of search results, creation of alerts, reference management, and the publication of results. With Open Science, permanent updates of skills are required. That is why new ways of approaching researchers that contribute to their information and training are not negligible. This case study has described how a university library responded strategically to the challenges of Open Science, in a simple manner but in line with the digital environment where the investigation is carried out.

\section{Conclusions}

Librarians have an extra responsibility because they have deep knowledge of information, its organisation, management, and access. They should disseminate this specific knowledge through training and informative actions. Researchers base much of their activity on information resources so they need to understand, access, evaluate, use, and manage a wide range of documents. That is why it is important to devote some time to learning new information organisation and management tools. As institutions dedicated to supporting learning and research, university libraries should pay close attention to the changes that technologies bring to the field of information, namely the Open Science movement.

The experience of the Library of the Faculdade de Psicologia and of the Instituto de Educação is just one example of how this adaptation has taken place. In the context in question, we sought to show how important it is to acknowledge the role of librarians 
as promoters of Open Science and trainers of teachers and researchers in these matters. For this purpose a specialised tutorial action was designed, as well as refresher training in thematic workshops and a digital informative sheet sent by email. These resources support continuity in the investment and update in electronic resources and the provision of refreshed information. All these strategies serve to describe and explain access, organisation, and sharing of information, building capacities in individuals for the Open Science movement. This capacity-building should be based mostly on the dialogue between these two professionals - librarians and researchers - so that both can converge towards common goals, aligning their interests and efforts.

The actions that librarians can develop at this level are essential, for they are the basis for the creation and development of transversal skills in which researchers are indispensable partners. A case study always implies the intrinsic limitations in that it is a circumscribed reality that is not always reproducible. In this case, in particular, it was not possible to deepen the context. Nevertheless, we believe that the ideas conveyed can be inspiring for other libraries that are faced with the task of teaching of information skills to teachers and researchers. In the future it would be important to follow the example of the international panorama and carry out in-depth studies consolidating the existing knowledge about researchers and their needs that would allow for a wider scope and impact of information literacy applied to Open Science.

Acknowledgements. A special thanks to Sofia Coelho, for the language translations and reviews.

\section{References}

1. Brown, M.L.: The role of the research library. In D. Shorley, M. Jubb (eds). The future of scholarly communication, pp. 158-68. London, Facet (2013)

2. European Comission Providing researchers with the skills and competencies they need to practise Open Science: Report of the Working Group on Education and Skills under Open Science. European Commission. Directorate-General for Research and Innovation. Open Science and ERA Policy Unit, (2017), https://cdn1.euraxess.org/sites/default/files/policy_library/ ec-rtd_os_skills_report_final_complete_2207_1.pdf

3. Carter, I. $\bar{M} .:$ Changing institutional research strategies. In D. Shorley, M. Jubb (eds). The future of scholarly communication, pp. 145-55. London, Facet (2013).

4. Raju, J.: Knowledge and skills for the digital era academic library. J. Acad. Librariansh., 40(2), 163-170 (2014)

5. Bendriss, R., Saliba, R., Birch, S.: Faculty and librarians' partnership: Designing a new framework to develop information fluent future doctors. J. Acad. Librariansh., 41(6), 821838 (2015).

6. Salem Jr, J.A.: Open pathways to student success: academic library partnerships for open educational resource and affordable course content creation and adoption. J. Acad. Librariansh, 43(1), 34-38. (2017).

7. Junisbai, B., Lowe, M.S., \& Tagge, N.: A Pragmatic and Flexible Approach to Information Literacy: Findings from a Three-Year Study of Faculty-Librarian Collaboration. J. Acad. Librariansh., 42(5), 604-611 (2016). 
8. Harvard-Williams, P.: Serviço universitário ou departamento de ensino? Cad. Biblio. Arquiv. Doc.. Coimbra, 9 (1) Jan. 1972, 31-35. [original 1957] (1972).

9. Kemp, J.: Isn't being a librarian enough? Librarians as classroom teachers. Coll. Undergrad. Libr., 13(3), 3-23 (2006).

10. Loesch, M. F.: Librarian as professor: A dynamic new role model. Educ. Librar., 33(1), 3137 (2010)

11. Wheeler, E., \& McKinney, P.: Are librarians teachers? Investigating academic librarians' perceptions of their own teaching roles. J. Infor. Lit., 9(2), 111-128, (2015)

12. Walter, S.: Instructional improvement: Building capacity for the professional development of librarians as teachers. Ref. User Serv. Q., 45(3), 213-218 (2006).

13. Grimes, D.J.: The Library-Classroom Link: History, Theory, and Application. Paper presented at the Cooperative Ventures Conference of the Combined Media Organizations of Georgia (2nd, Jekyll Island, GA, March 9). ERIC (1993)

14. Phelps, S. F., \& Campbell, N.: Commitment and trust in librarian-faculty relationships: A systematic review of the literature. J. Acad. Librariansh, 38(1), 13-19 (2012)

15. Creaser, C., \& Spezi, V.: Working together: evolving value for academic libraries. A report commissioned by SAGE. Loughborough University, SAGE (2012)

16. Montiel-Overall, P., \& Grimes, K.: Teachers and librarians collaborating on inquiry-based science instruction: A longitudinal study. Librar. Inf. Sci. Res., 35(1), 41-53 (2013)

17. Nichols, S.G.: Co-teaching: The library and me. No brief candle: Reconceiving research libraries for the 21st century, 28-34. Council on Library \& Information Resources. (2008).

18. Harada, V.H.: Librarians and teachers as research partners: reshaping practices based on assessment and reflection. Scho. Librar. Worldw., 11(2), 49-72 (2005)

19. Dillon, A.: Accelerating learning and discovery: Refining the role of academic librarians. No brief candle: Reconceiving research libraries for the 21st century, 51-57. Council on Library \& Information Resources (2008)

20. Cruz, M.L.G., Rebolho, I.M.C.: A Biblioteca da Faculdade de Letras da Universidade de Lisboa num Novo Paradigma de Ensino: Recursos e Colaboração na Inovação Pedagógica. In Cruz, Ana Pinto da (ed.), Bibliotecas, Leitura, Património: práticas educativas. O ideário patrimonial (Vade-mécum Série Monográfica, 2), pp.133-146. Tomar, Centro de PréHistória, Instituto Politécnico de Tomar (2015) http://www.cph.ipt.pt/download/OIPDownload/vade mecum/n2/Vade 2.pdf

21. Antunes ML, Silva C, Reis C.: Uma cultura de colaboração entre professores e bibliotecários: a orientação tutorial de estudantes de radiologia no ISCISA (Maputo). In Actas do $12^{\circ}$ Congresso Nacional de Bibliotecários, Arquivistas e Documentalistas - Ligar, Transformar, Criar Valor, Universidade de Évora, 21-23 de outubro (2015) http://www.bad.pt/publicacoes/index.php/congressosbad/article /view/1283

22. Auckland, M.: Re-skilling for research: An investigation into the role and skills of subject and liaison librarians required to effectively support the evolving information needs of researchers. RLUK Report (2012) http://www.rluk.ac.uk/wpcontent/uploads/2014/02/RLUK-Re-skilling.pdf

23. Yevelson-Shorsher, A., \& Bronstein, J.: Three Perspectives on Information Literacy in Academia: Talking to Librarians, Faculty, and Students. Coll. Res. Librar., 79(4), 535-553 (2018). 
24. Erlinger, A.: Outcomes Assessment in Undergraduate Information Literacy Instruction: A Systematic Review. Coll. Res. Librar., 79(4), 442-479 (2018).

25. Streatfield, D.R., Allen, D., \& Wilson, T.D.: Mind the skills gap: informationhandling training for researchers. London, The Research information Network (2008)

26. Facilitate Open Science Training For European Re-search [FOSTER]: The Open Science Training Handbook (2017) https : / book. fosteropenscience.eu/

27. OCDE: Making open science a reality. Paris, OECD Publishing (2015)

28. European Commission: What is open science? FAQs on the open science policy platform. Brussels, European Commission (2016). https : / /ec.europa.eu/research/ openscience/index.cfm?pg=open-science-policy-platform-faqs

29. Fecher, B., Friesike, S.: Open science: One term, five schools of thought. Opening science, pp. 17-47. Springer, Cham (2014)

30. Council on Library, and Information Resources: No brief candle: reconceiving research libraries for the 21st century. No. 142. Council on Library \& Information Resources (2008)

31. Brown, S., Swan, A.: Researchers' use of academic libraries and their services: a report. Research Information Network and the Consortium of Research Libraries. RIN, CURL (2007)

32. Bawden, D.: The Future of Research and the Research Library: A Report to DEFF. Dansk Biblioteksforskning 5. 2/3, 77-1 (2009)

33. Brown, S., Keene, C, Bruce, R, Lynch, C.: International advances in digital scholarship. Jisc and CNI conference, July 2016, Oxford University. UK Oxford, Jisc, CNI (2016)

34. Secretaria de Estado da Ciência, Tecnologia e Ensino Superior [SECTES]. Ciência Aberta: conhecimento para todos. Lisboa, SECTES (2016)

35. Revez, J., Borges, M.M., Silva, C.G.: O papel das bibliotecas na investigação científica: um estado da arte. In A Ciência Aberta: o Contributo da Ciência da Informação: atas do VIII Encontro Ibérico EDICIC, pp. 943-954. Coimbra, Universidade de Coimbra. Centro de Estudos Interdisciplinares do Século XX - CEIS20 (2017)

36. Caraça J.: Para abrir a ciência. In: Cardoso G., Jacobetty P., Duarte A., (eds). Para uma Ciência Aberta, pp. xiii-xv .Lisboa: Mundos Sociais (2012)

37. Revez, J.: Opening the Heart of Science: A Review of the Changing Roles of Research Libraries. Publications, 6(1), 9 (2018)

38. Antunes, M.L., Sanches, T., Lopes, C., Rodrigues, B.S. Literacia da informação: o primeiro degrau para a Ciência Aberta. In Borges, M. M. \& Sanz Casado, E. (Coords.). A Ciência Aberta o contributo da Ciência da Informação: Atas do VIII Encontro Ibérico EDICIC, 2022 Novembro. pp. 47-56. Coimbra: Universidade de Coimbra. Centro de Estudos Interdisciplinares do Século XX - CEIS20 (2017)

39. Streatfield, D.R., Allen, D., Wilson, T.D. Mind the skills gap: information handling training for researchers: a report. London: The Research information Network (2008)

40. Bewick, L., Corrall, S.: Developing librarians as teachers: A study of their pedagogical knowledge. J. Librarians. Inf. Sci., 42(2), 97-110 (2010). https://doi $10.1177 / 0961000610361419$

41. Revez, J.: A formação de docentes e investigadores e as bibliotecas académicas: um desafio e uma proposta. Cad. BAD, 1, 155-171 (2014) 
42. Sanches, T.: Estimular a ciência aberta: comunicando com docentes e investigadores. XIII Jornadas APDIS bibliotecas da saúde: Da Ciência Aberta à Investigação e Prática Clínica. 14-16 Março. Lisboa, APDIS (2018)

43. Vaughan K.T.L., Hayes, B.E., Lerner, R. C., McElfresh, K.R., Pavlech, L., Romito, D . . Morris, E. N.: Development of the research lifecycle model for library services. J. Med. Librar. Assoc., 101(4), 310-314 (2013) https://doi.org/10.3163/15365050.101 .4 .013

44. Basili, C.: Information literacy requirements for open science. In: Sales, D., Pinto, M. (eds). Pathways into information literacy and communities of practice, pp. 229-48. Amsterdam: Chandos Publishing (2017) 